antibodies to ceroid, and there is an exciting possibility that these antibodies may in future be used as markers of the activity of the disease. ${ }^{32}$

NIGEL BULLOCK

Consultant Urologist,

Addenbrooke's Hospital,

Cambridge CB2 2QQ

1 Van Niekerk JPdeV. Diagnosis and management of retroperitoneal fibrosis. S Afr Med $\mathcal{J}$ 1982;62:193-5.

2 Kerr WS Jr, Suby HI, Vickery A, Fraley E. Idiopathic retroperitoneal fibrosis: clinical experience with 15 cases, 1956-1967. J Urol 1968;99:575-84.

3 Stecker JF, Rawls HP, Devine CJ, Devine PC. Retroperitoneal fibrosis and ergot derivatives. f Urol 1974;112:30-2.

4 Thompson J, Julian DG. Retroperitoneal fibrosis associated with metoprolol. Br Med $\mathrm{f}$ $1982 ; 284: 83-4$.

Laasko M, Arvala I, Tervonen S, Sotarauta M. Retroperitoneal fibrosis associated with sotalol. BrMed f 1982;285: 1085-6.

6 Lewis CT, Molland EA, Marshall VR, Tresidder CG, Blandy JP. Analgesic abuse, ureteric obstruction and retroperitoneal fibrosis. Br Med $\mathcal{J}$ 1975; $;$ ii: 76-8

Pryor JP, Castle WM, Dukes DC, Smith JC, Watson ME, Williams JL. Do beta-adrenoceptor Pryor JP, Castle WM, Dukes DC, Smith JC, Watson ME, Williams JL.
blocking drugs cause retroperitoneal fibrosis? Br Med f 1983;287:639-41.

8 Mitchinson MJ. The pathology of idiopathic retroperitoneal fibrosis. F Clin Pathol 1970;23:681-9. 9 Duffy PG, Johnston SR, Donaldson RA. Idiopathic retroperitoneal fibrosis in twins. $\mathcal{J}$ Urol 1984;131:746.

10 Birnberg FA, Vinstein AL, Gorlick G, Lee FA, Hales MA. Retroperitoneal fibrosis in children. Radiology 1982;145:59-61.

11 Snow BW, Garrett RA. Retroperitoneal fibrosis in children (eosinophilic and idiopathic). Urolog $v$ 194;23:569-72.

12 Degeys GE, Dunnick NR, Silverman PM, Cohan RH, Illescas FF, Castagno A. Retroperitoneal fibrosis: use of computerized tomography in distinguishing among possible causes. Am $\mathcal{J}$ Radiol 1986;146:57-60.
13 Dixon AK, Mitchinson MJ, Sherwood T. Computed tomographic observations in periaortitis: a hypothesis. Clin Radiol 1984;35:39-42.

14 Hricak H, Higgins CB, Williams RD. Nuclear magnetic resonance imaging in retroperitoneal fibrosis. Am 7 Radiol 1983;141:35-8.

15 Tresidder $\mathrm{CG}$, Blandy JP, Singh $M$. Omental sleeve to prevent current retroperitoneal fibrosis around the ureter. Urol Int 1972;27:144-8.

16 Baker LRI, Mallinson WJW, Gregory MC, et al. Idiopathic retroperitoneal fibrosis. A retrospective analysis of 60 cases. Br $\mathcal{A}$ Urol 1988;60:497-503.

17 Silk M, Silk M. Silastic sheeting in retroperitoneal fibrosis. Urology 1984;24:125-7.

18 Deane AM, Gingell JC, Pentlow BD. Idiopathic retroperitoneal fibrosis- the role of autotransplantation. Br f Urol 1983;55:254-6.

19 Chartton CAC. The use of steroids in a form of retroperitoneal fibrosis. Proceedings of the Royal Society of Medicine 1986;61:875-6.

20 Ross JC, Goldsmith HJ. The combined surgical and medical treatment of retroperitoneal fibrosis. BrF Surg 1971;58:422-7.

21 Ochsner MG, Brannan W, Pond HS, Goodlet JS Jr. Medical therapy in idiopathic retroperitoneal fibrosis. J Urol 1975;114:700-3.

22 Rauws EAJ, Mallens WMC, Bieger R. CT scanning for the follow-up of corticosteroid treatment of primary retroperitoneal fibrosis. Journal of Computer Assisted Tomography 1983;7:113-6.

23 Brooks AP, Reznek RH, Webb JAW, Baker LRI. Computed tomography in the follow-up of retroperitoneal fibrosis. Clin Radiol 1987;38:597-601.

24 Wright FW, Sanders RC. Is retroperitoneal fibrosis a self-limiting disease? Br $\mathcal{J}$ Radiol 1971;44:511-4.

25 Tiptaft RC, Costello AJ, Paris AMI, Blandy JP. The long-term follow-up of idiopathic retroperitoneal fibrosis. Br f Urol 1982;54:620-4.

26 Mundy AR, Kinder $\mathrm{CH}$, Flannery JF, Joyce MRL. Hypertension and thromboembolism in idiopathic retroperitoneal fibrosis. Br f Urol 1982;54:625-7.

27 Mitchinson MJ. Aortic disease in idiopathic retroperitoneal and mediastinal fibrosis. $7 \mathrm{Clin}$ Pathol 1972;25:287-93.

28 Parums D, Mitchinson MJ. Demonstration of immunoglobulin in the neighbourhood of advanced atherosclerotic plaques. Atherosclerosis 1981;38:211-6.

29 Parums DV, Chadwick DR, Mitchinson MJ. The localisation of immunoglobulin in chronic periaortitis. Atherosclerosis 1986;61:117-23.

30 Liebmann RM. Positive gallium scan in retroperitoneal fibrosis. Am $\mathcal{J}$ Radiol 1983;141:949-50.

31 Mitchinson MJ. Retroperitoneal fibrosis revisited. Arch Pathol Lab Med 1986;110:784-6.

32 Mitchinson MJ. Insoluble lipids in human atherosclerotic plaques. Atherosclerosis 1982;45:11-5.

\title{
Alcohol services: exhortations rather than commitment
}

\author{
Many problem drinkers cannot find specialist help
}

Alcohol is a source of pleasure, profit, employment, tax revenue on a large scale ( $\$ 11000$ a minute), and a casualty toll that is growing steadily. An average health district is likely to contain 10-15000 people who are drinking more than is sensible, have problems from their drinking, or are dependent on alcohol. A 1978 government advisory committee recommended that "every person with a drinking problem should be able to find the help he or she needs" and emphasised the importance of primary care workers backed up by local counselling and specialist services. ' Yet a year later the Royal College of Psychiatrists reported that "despite all the dedicated effort, and the many successes, society has largely been pretending to mount a treatment response to alcoholism."' In the same year so worrying were the conclusions of a government think tank report on the future of statutory services that it was suppressed, ${ }^{3}$ while a report on the voluntary sector's response to alcohol problems found "serious deficiencies."

Present services for problem drinkers are many and diverse and both statutory and voluntary. Specialist services include community alcohol teams, advisory and counselling services, day centres, residential projects, alcohol treatment units, detoxification facilities, self help groups, and private clinics. Yet despite the government's previous exhortations and criticisms a review by Alcohol Concern of services in England and Wales makes depressing reading. ${ }^{5}$ Three regional health authorities in the south do not have a specific policy of planning services. In the north, where there are policies, there are, for example, "substantial gaps in provisions and uncertain funding in Yorkshire," while in the West Midlands "services are woefully inadequate and either non-existent or minimal." In greater London only nine out of 32 boroughs have an adequate service. What is strikingly obvious from Alcohol Concern's report is that the voluntary sector has displayed most initiative; it is the statutory sector and central government that have failed to act.

Many problem drinkers cannot find the help they need. For example, admission of women to psychiatric units for problems related to alcohol increased by $23 \%$ between 1979 and 1984, yet most residential services are for men only; furthermore, women who are married cannot claim board and lodging from the Department of Health and Social Security, barring all but the wealthy from residential care. Similarly between $0.5 \%$ and $10 \%$ of older people have alcohol problems-yet no alcohol agencies exist specifically for older or retired people. Meanwhile, among the young, 39\% of drivers aged 20-24 who are killed in road accidents have blood alcohol concentrations over the legal limit yet the government's educational campaign directed at the young has bein described as of "questionable efficacy without adequate enforcement." People from ethnic minorities are underrepresented among the staff of alcohol agencies and many people from ethnic minorities are probably being received into acute psychiatrict care because of disturbed behaviour that may be related to alcohol. Finally, services in which a whole family could participate in the treatment seem to be non-existent. ${ }^{5}$

The government wants to have its cake and eat it: some departments are interested in boosting the production of alcohol-for example, by giving grants to new plants producing alcohol-while the DHSS and Home Office bemoan the crime and sickness associated with alcohol. ${ }^{3}$ Doctors in general have little knowledge of alcohol and a high prevalence of alcohol problems, which may explain their ambivalence in acting despite evidence that simple advice about cutting down drinking from a doctor is effective in as many as two thirds of heavy drinkers. ${ }^{7}$ The voluntary sector, which provides most of the skills in services for problem drinkers, 
has been set up to fail because of uncertain funding and unclear objectives and goals.

How best then to organise services in the future? Firstly, the health service needs to put its own house in order and lead by example as happened with smoking. More specifically, there should be easier access to beds for detoxification and more action oriented research. In general practice patients should be routinely asked about alcohol consumption. ${ }^{8}$ Social services and probation services should provide in house training on alcohol problems and should appoint specialist officers. The statutory health sector must attempt to correct the gross regional disparities. Needs for special groups should be identified, and research and training deserve priority. It is a scandal that there are no academic departments of substance abuse in undergraduate medical schools; teaching on alcohol in the medical schools must be improved.

All of this is predicated on central government support, and we must wait and see whether the international committee on alcohol problems will have any fiscal or legislative teeth. Three achievements would show its commitment: increasing further the price of alcohol, reducing the availability of alcohol, and enforcing the law on underage drinking and drink-driving. ${ }^{9}$ Change at the grass roots will be pointless without solid and cohesive central government support and funding.

Senior Registrar,

PCAVISTON

Department of Child, Adolescent, and Family Psychiatry,

University College and Middlesex Hospitals,

London W1N 8AA

1 Department of Health and Social Security. The pattern and range of services for problem drinkers. London: HMSO, 1978

Special Committee of the Royal College of Psychiatrists. Alcohol and alcoholism. London: Tavistock Publications, 1979.

3 Smith R. Action on alcohol-at last. Br.Med J 1987;295:740

Department of Health and Social Security. National voluntary organisations and alcohol misuse. London: DHSS, 1982.

Brennan E, Conyngham G, Cooke C, Guthrie P, Mackewan I, Pappenheim K. Alcohol services: the future? London: Alcohol Concern, 1987.

6 Clare A, Bristow M. Drinking drivers: the needs for research and rehabilitation. Br Med $\mathrm{f}$ 1987:295:1432-3

Special Committee of the Royal College of Psychiatrists. Alcohol: our favourite drug. London: Tavistock Publications, 1986.

8 Special Committee of the Royal College of General Practitioners. Alcohol-a balanced view. London: RCGP, 1986.

9 Royal College of Physicians. Working Party on Alcohol. Medical consequences of alcohol abuse: a great and growing evil. London: RCP, 1987

\section{Continuous arteriovenous haemodialysis}

\section{May be used in intensive care}

Ideally any intensive care unit should be able to treat patients whose kidneys have failed completely. Until recently the mainstay of such treatment has been intermittent haemodialysis. As haemodialysis is often complicated by cardiovascular instability in such critically ill patients and as haemodialysis is limited to specialist centres other methods of renal replacement treatment have been developed. Peritoneal dialysis may be performed in non-specialist centres but is not suitable for patients who are being ventilated or those who have had an abdominal operation. Continuous arteriovenous haemofiltration was introduced by Kramer et al in $1977^{\prime}$ and is now part of the standard management of acute renal failure. ${ }^{23}$ It is a simple technique to use as a blood pump is not required. The volume of ultrafiltrate generally obtained $(500-800 \mathrm{ml} / \mathrm{h})$ does not, however, provide enough clearance of small molecules to avoid the need for intermittent haemodialysis. It is possible to increase clearance of small molecules by increasing the ultrafiltrate volume with a venovenous blood pump, but this adds to the risks of air emboli and inaccurate replacement of fluid.

Continuous arteriovenous haemodialysis combines slow diffusion with convective ultrafiltration to provide increased clearances-thereby eliminating the need for intermittent haemodialysis. Blood flow is denendent solely on the arteriovenous pressure difference (usually through a Scribner shunt or femoral arterial and venous lines) without the pitfalls of blood pumps. ${ }^{45}$ Both flat plate and hollow fibre haemodialysers are available. High flux membranes such as polyacrylnitrile or polysulfone allow rates of ultrafiltration similar to those of continuous arteriovenous haemofiltration. The dialysis fluid is run through the dialysis compartment at $1-2 \mathrm{l} / \mathrm{h}$. Because of the slow rate of flow complete equilibration should occur between blood and the dialysis fluid. Thus if the rate of flow of the dialysis fluid is $11 / \mathrm{h}(16.5 \mathrm{ml} / \mathrm{min})$ the urea diffusive clearance would be $16.5 \mathrm{ml} / \mathrm{min}$. If higher clearances are required-for example, in patients in a catabolic statethe rate of flow of the dialysis fluid may be increased to $2 \mathrm{l} / \mathrm{h}$.
Continuous arteriovenous haemodialysis is a simple technique that may be managed entirely by staff in intensive care units. Urea clearances are high enough to control the plasma urea concentration without any additional intermittent haemodialysis even in patients in a severe catabolic state. In our experience the plasma urea concentration falls during the first two days of continuous arteriovenous haemodialysis and may then be kept within a constant range of 11-30 mmol/l. Dysequilibirium is avoided by this gradual fall in plasma urea concentrations. In addition, no cardiovascular instability occurs as the fluid balance is easily controlled by measuring the outflow volume (inflow of dialysis fluid plus ultrafiltrate volume) and controlling the fluid input.

Continuous arteriovenous haemodialysis is an important advance in managing acute renal failure. Although it has been described elsewhere, ${ }^{45}$ it has become available only recently in Britain. It means that patients who need renal replacement treatment while in an intensive care unit may be managed in hospitals that do not have an associated renal unit. This is particularly important because doctors may commonly have to approach several renal units, often many miles away, before a bed can be found for a patient.

E A BROWN

Senior Registrar, Department of Medicine W KOX

Charing Cross Hospital Senior Lecturer, Department of Anaesthesia

London W6 8RF

\footnotetext{
Kramer A, Wigger W, Rieger J. Arteriovenous haemofiltration; a new and simple method for reatment of overhydrated patients resistant to diuretics. Klin Wochenschr 1977;55:1121-2.

2 Kaplan AA, Longnecker RE, Folkert VW. Continuous arteriovenous hemofiltration. A report on six months' experience. Ann Intern Med 1984;100: 358-67.

3 Golper TA. Continuous arteriovenous hemofiltration in acute renal failure. Am $\mathcal{J}$ Kidney Dis 1985;6:373-86.

4 Raja R, Kramer S, Goldstein S, Caruana R, Lerner A. Comparison of continuous arteriovenous hemofiltration and continuous arteriovenous dialysis in critically ill patients. TransactionsAmerican Society for Artificial Intermal Organs 1986;32:435-6.

Sigler M, Teehan BP, Van Valkenburgh D. Solute transport in continuous hemodialysis: a new treatment for acute renal failure. Kidney Int 1987;32:562-71.
} 